\title{
EXPLORING THE USE OF MULTILITERACIES PROJECT APPROACH TO ENHANCE EMPLOYABILITY SKILLS AMONG MALAYSIAN UNIVERSITY GRADUATES
}

\author{
Fariza Puteh Behak ${ }^{1 *}$, Normazla Ahmad Mahir ${ }^{2}$, Yurni Emilia Abd Hamid ${ }^{3}$, Suzanah \\ Selamat ${ }^{4}$, Suraini Mohd $\mathrm{Ali}^{5}$, Ramiaida Darmi ${ }^{6}$, Haliza Harun ${ }^{7}$, Norhaili Massari ${ }^{8}$, Noor \\ Saazai Mat Saad ${ }^{9}$, Harison Sidek ${ }^{10}$ \\ ${ }^{1}$ Dr., Universiti Sains Islam Malaysia, Malaysia, fariza@usim.edu.my \\ ${ }^{2}$ Ms., Universiti Sains Islam Malaysia, Malaysia, normazla@usim.edu.my \\ ${ }^{3}$ Ms., Universiti Sains Islam Malaysia, Malaysia, yurni@usim.edu.my \\ ${ }^{4}$ Ms., Universiti Sains Islam Malaysia, Malaysia, suzanah@usim.edu.my \\ ${ }^{5}$ Dr., Universiti Sains Islam Malaysia, Malaysia, suraini@usim.edu.my \\ ${ }^{6}$ Dr., Universiti Sains Islam Malaysia, Malaysia, ramiaida@usim.edu.my \\ ${ }^{7}$ Dr., Universiti Sains Islam Malaysia, Malaysia, haliza@usim.edu.my \\ ${ }^{8}$ Ms., Universiti Sains Islam Malaysia, Malaysia, norhaili@usim.edu.my \\ ${ }^{9}$ Dr., Universiti Sains Islam Malaysia, Malaysia, noorsaazai@usim.edu.my \\ ${ }^{10}$ Assoc. Prof., Universiti Sains Islam Malaysia, Malaysia, harison@usim.edu.my \\ ${ }^{*}$ Corresponding author
}

\begin{abstract}
Enhancing $21^{\text {st }}$ century learning skills becomes the utmost importance in the contemporary education world. In Malaysia, the rising number of unemployment among Malaysian university graduates is associated to the lack of $21^{\text {st }}$ century skills and it is imperative to find a pedagogical approach that could enhance these skills. This study examines how Multiliteracies Project Approach (MPA) enhances $21^{\text {st }}$ century skills among Malaysian university graduates. It is a qualitative study that was conducted at a public university in Nilai, Malaysia, involving 50 students enrolled in English as a Second Language (ESL) course. Data was collected using qualitative tools such as observation, semi-structured interviews and reflective journals. Data was then analyzed using a thematic analysis method. The findings of the study showed that MPA promotes the development of collaborative, technological and critical thinking skills among students. MPA provided students the chance to practice working effectively in in a network of people to achieve a mutual goal. Findings also showed that students acquired new skills when learning using MPA, including technological skills and critical thinking skills which were significant in $21^{\text {st }}$ century employment. The findings suggest that Multiliteracies Project Approach can provide a significant pedagogical implication.
\end{abstract}

Keywords: multiliteracies, $21^{\text {st }}$ century skills, pedagogical implication 


\section{INTRODUCTION}

Beginning $21^{\text {st }}$ century, one of the many focus of the academia was the employability skills among university graduates. Graduate employability is often a problem in Malaysia. However, recently, the unemployability rate among graduates is increasing rapidly in Malaysia. A study by Ooi (2016) shows that up to 161,000 or $8.8 \%$ of graduates aged between 20 and 24 are expected to be unemployed in Malaysia this year). This is more than double the number of unemployed graduates in 2013, which was at 52, 282, whereas in 2010 the number of undergraduates were at 42,954 . Among the reasons for the rapid increase is the fact that there is a lack of employability skills among university graduates whereby there is a gap that exists between employers' expectations and graduate's abilities. Hence, the Malaysian Ministry of Education has taken several initiatives to reduce this gap. In 2013, the Malaysian government initiated the Graduate Employability Blueprint to meet the demand of the industry and solve the issue of high employment rate of Malaysian undergraduates. The Graduate Employability Competencies (GEC) is part of the blueprint which serves as a guide for Malaysian university curriculum. The GEC ensures that employable attributes such as communication skills, collaborative skills and technological competence are integrated into the university curriculum.

With the implementation of GEC, universities are looking at new approaches to ensure that they are able to meet the above attributes. Hence, this study investigates the use of one of the new teaching approaches known as Multliteracies Project Approach (MPA) in teaching English at public universities. This study presents the theoretical background of MPA, methodology of the study which includes the research procedures, data collection and data analysis tools as well as the MPA project. Subsequently, the paper discusses findings of the study and concludes with a discussion and the pedagogical implications.

\section{MULTILITERACIES PROJECT APPROACH AND $21^{\text {ST }}$ CENTURY SKILLS}

\subsection{Multiliteracies Project Approach (MPA)}

Multiliteracies Project Approach (MPA) is a pedagogical approach that combines two established teaching approaches which are: the multiliteracies approach and project-based learning (Fariza Puteh-Behak \& Suzanah Selamat, 2017).

The notion of multiliteracies was established due to the transformation and advancement of technology and global economy (Cope \& Kalantzis, 2009a; Hepple, Sockhill, Tan \& Alford, 2014; The New London Group, 2000). In the $21^{\text {st }}$ century, learning is about having the knowledge and skills that are necessary for learners to understand, discuss, reflect and use multiple representations of texts to participate effectively in a variety of formal and social situations (Cope \& Kalantzis, 2009a; Fariza Puteh-Behak, Ramiaida Darmi \& Yuslina Mohamed, 2015; Hepple, Sockhill, Tan \& Alford, 2014; The New London Group, 2000). Multiliteracies approach emphasizes knowledge process such as experiencing, conceptualising, analysing and applying that is significant to function effectively in the $21^{\text {st }}$ century (Cope \& Kalantzis, 2009a, 2009b). In addition, the multiliteracies approach also emphasizes the use of multimodal resources that incorporate print, audio, visual, gestural, spatial representations; which are present in the digital texts in the $21^{\text {st }}$ century (Cope \& Kalantzis, 2009a; Charles, 2008; Simon, 2011; The New London Group, 2000)

Meanwhile, project-based learning emphasizes learning activities that are student-centered and interdisciplinary (Creghan \& Adair-Creghan, 2015; Markham, 2011). The main emphasis of project-based learning is engaging students in authentic situation and meaningful learning situations(Chaichompoo, 2013). In project-based learning, students learn knowledge and elements of the core curriculum, but also apply what they know to solve authentic problems and produce relevant results (Creghan \& Adair-Creghan, 2015). In the course of the project, students were engaged in diverse knowledge process such as asking and refining questions, debating ideas, making predictions, designing plans and/or experiments, collecting and analyzing data, drawing conclusions, communicating their ideas and findings to others, asking new questions, and creating artifacts (Creghan \& Adair-Creghan, 2015; Markham, 2011).

MPA combines both the core elements of the multiliteracies approach and project-based learning. The main feature of MPA is the interconnectedness between all lessons in the classroom, curriculum requirements, knowledge process and the use of technological tools. All lessons are connected to the completion of one MPA project. This is to ensure that the students will have a meaningful learning. In the course of completing the MPA project, students will use relevant tools including traditional and technological tools. At the same time, students will participate in activities that cultivate $21^{\text {st }}$ century knowledge process (Fariza Puteh-Behak \& Suzanah Selamat, 2017). 


\section{2. $21^{\text {st }}$ Century Skills}

This brings us to the next important question, what knowledge and skills are considered significant in the $21^{\text {st }}$ century?

It has been established that technologies have transformed the way people do things in the $21^{\text {st }}$ century and it is crucial for $21^{\text {st }}$ century learners to have the knowledge and skills of understanding and using technologies and multimodal (two or more communication modes to make meaning inclusive of image, gesture, music, spoken language, and written language) representation of texts (Borsheim et al., 2008; Grabill \& Hicks, 2008; The New London Group, 2000). Kist (2003) emphasized this point when he asserted that learners who are fluent in understanding, discussing and reflecting multiple codes that are required by the current multimodal texts are considered successful $21^{\text {st }}$ century learners. At the same time, $21^{\text {st }}$ century learners need to be able to be flexible and fluid to keep up with the fast-changing nature of the technologies. Leu et al. (2004) suggested that a multiliterate learner not only needs to be able to use technologies but also need to have the ability to use technologies to identify information, and be involved in critical thinking skills such as analysing and synthesizing. They stressed that the students should have the ability to use technology to convey the analysis to other people.

The new literacies of the Internet and other ICTs include the skills, strategies, and dispositions necessary to successfully use and adapt to the rapidly changing information and communication technologies and contexts that continuously emerge in our world and influence all areas of our personal and professional lives. These new literacies allow us to use the Internet and other ICTs to identify important questions, locate information, critically evaluate the usefulness of that information, synthesize information to answer those questions, and then communicate the answers to others (Leu et al., 2004, p. 1572).

This point was discussed by Anstey and Bull (2006) where they described a multiliterate person as someone who

is flexible and strategic and can understand and use literacy and literate practices with a range of texts and technologies; in socially responsible ways; in a socially, culturally, and linguistically diverse world; and to fully participate in life as an active and informed citizen (p. 55).

So, the use of technologies is more comprehensive than using technologies as tools. It is also about having the critical thinking skills to analyse and reflect and synthesize information that is presented through contemporary technological tools. Silva (2009) stated that the current workforce is required to have the ability to find and critically analyze information from various sources. Savedra and Opfer (2012) argued that $21^{\text {st }}$ century skills could be defined as many things but all definitions are relevant to contemporary life in the complex world of the $21^{\text {st }}$ century.

In addition, $21^{\text {st }}$ century skills also revolve around the ability to work in teams and in a network of people (Gee, 2000, 2002; Iyer \& Luke, 2010; Kist, 2003; McComas, 2014, Saavedra \& Opfer, 2012; Rotherham \& Williamham, 2010). Collaboration was also listed as one of the essential $21^{\text {st }}$ century skills in the Framework for $21^{\text {st }}$ Century Learning (P21 Partnership for $21^{\text {st }}$ Century Learning, 2016). According to the framework, students of the $21^{\text {st }}$ century should be able to demonstrate the ability to work "effectively and respectfully" in a network of people to accomplish a common goal (http://www.p21.org/about-us/p21-framework/261communication-and-collaboration).

Gee (2000) asserted that in addition to having the skills to work collaboratively, a worker is currently expected to be more proactive in relation to the interest of the workplace. This means that a worker regardless of his/her level in the organization structure is required to be able to conduct critical analysis and possess multiple skills. Ultimately, the $21^{\text {st }}$ century is demanding that learners or future workers be experts in a variety of fields and do not only possess a single expertise (Gee, 2000).

In short, based on the discussions above, the $21^{\text {st }}$ century skills that will be highlighted in the current paper are:

1. knowledge to use current technologies for diverse purposes;

2. critical thinking skills to identify, reflect, analyse and evaluate information presented by multimodal texts;

3. ability to work in teams and on peer-collaborative tasks.

\section{METHODOLOGY}

\subsection{Site and Participants}

This study was conducted at Universiti Sains Islam Malaysia, involving 50 students from two English for Communicative Purposes (ECP) classes. The students aged from 19 to 20 years old were in their first year 
of undergraduate study in the Faculty of Quran and Sunnah. All students scored Band 3 in Malaysian English University Entrance Test (MUET), which means the students have intermediate English language proficiency level. Out of the 50 students, 10 students were invited to be the focus group. The selection of the focus group was voluntary-based.

\subsection{MPA Project}

As part of the MPA module, the students were to complete an MPA project. In this study, the project is named Majalah USIM (USIM magazine). In Majalah USIM, the participants were to produce a video documentary that describes and analyzes a significant issue in USIM's community. At the end of the lesson, it is expected that the students will be able to; 1 ) Identify issues that are significant in their own community; 2) Conduct a research project to investigate issues in in-depth manner, and 3) Analyze and discuss these issues in a form of a documentary, using online tools and resources. The learning sequence to complete the multiliteracies project is shown in Table 1.

Table 1: The MPA project learning sequence

\begin{tabular}{|l|l|}
\hline Step & \multicolumn{1}{|c|}{ MPA Tasks } \\
\hline 1 & Students form small focus group and identify significant issues in their community \\
\hline 2 & $\begin{array}{l}\text { Through a teacher-directed discussion, the teacher draw attention to how to research an } \\
\text { issue in their own community . }\end{array}$ \\
\hline 3 & $\begin{array}{l}\text { Each focus group conducts a mini research by creating questionnaires using online tools as } \\
\text { well as reading articles and online resources. }\end{array}$ \\
\hline 4 & $\begin{array}{l}\text { Each focus group analyze the data they obtained from questionnaires as well as search for } \\
\text { related information online or in the library. }\end{array}$ \\
\hline 5 & $\begin{array}{l}\text { Each focus group discuss and decide how to present their issues in a 10-minute visual } \\
\text { documentary }\end{array}$ \\
\hline 6 & $\begin{array}{l}\text { Each focus group shares their documentary with the whole class. Students and teachers } \\
\text { provide feedback based on the documentary. }\end{array}$ \\
\hline
\end{tabular}

\subsection{Research Procedure, Data Collection and Data Analysis Methods}

As depicted in Figure 2, the first phase of the research is an orientation session where the participants were briefed about the study and subsequently invited to participate in the research project. This phase includes interviewing the focus group to obtain data on the students' previous English language learning experiences. A digital recorder was used to record data from the interviews.

At the implementation phase, students underwent 14 weeks (one semester) of classes whereby MPA was implemented and integrated into the lessons. At this stage, the participants were required to complete all MPA tasks and at the same time, the researcher (first author), who was also the instructor of the two classes, observed the participants' learning experiences. Furthermore, substantial events were also recorded.

The third phase of the study involved the collection of data on the participants learning experiences using MPA. Data were collected through post-intervention interviews with the focus group. At the same time, the participants' learning journals where they recorded their experiences learning through MPA were collected. Classroom artefacts which consisted of students' classroom documents and assignments as well as their video documentaries were also collected.

The final phase of the research was the analyses of data collected. First, data from the interviews were transcribed verbatim and analysed using play-script transcription technique where emphasis was given on 'what' was said rather than 'how' it was said. Next, thematic analysis approach was used to analyse the data whereby all data were categorised, coded and organised into significant themes. 


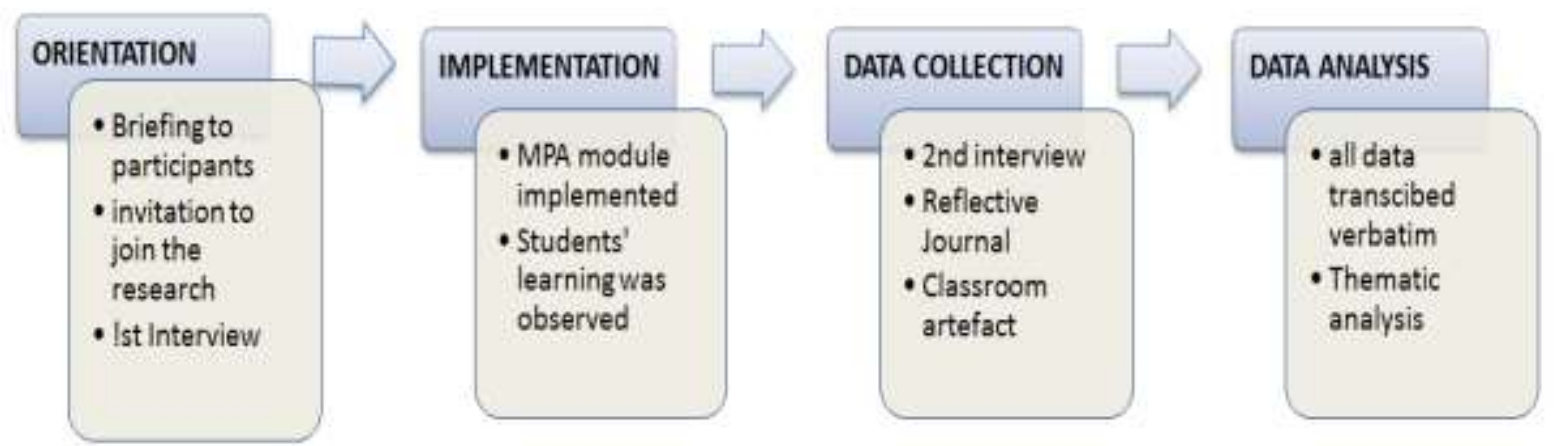

Fig 1. Research procedure

\section{FINDINGS AND DISCUSSION}

There were a few significant findings obtained by the current research project, however the current paper will focus on two essential findings which are MPA promotes $21^{\text {st }}$ century skills such as collaborative, technological and critical thinking skills. The discussion of findings is evidenced by original excerpts from interviews and reflective journal entries; hence some may contain error in terms of grammar and language expressions. These errors are however understood by the researchers as they shared similar socio-cultural background with the participants.

\subsection{Practicing collaborative skills}

The participants claimed that they enjoyed learning using MPA because it gave them an opportunity to work in teams. BS18 claimed that she loved learning using MPA because she had learnt on how to communicate with her teammates. "Yes, I like the learning experience through research/survey and producing video presentations because can expose to me on how to create good video, to communicate with others" (BS18). This statement was also supported by AS8 as she mentioned that the collaborative tasks in MPA made her feel excited. "I feel excited to producing video together" (AS8). BS9 stated that she liked MPA because of the cooperation between her group members. According to BS9, her group worked together harmoniously in completing the MPA project. "I like it , First, the reason is the cooperation of my group. They give full cooperation and attention during complete our survey task" (BS9). This point was also shared by BS10 and AS22 as both recounted on their experiences on working collaboratively in MPA. BS10 expressed her deep interest on learning using MPA because she and her groupmates had a lot of discussion, and in the process they were involved in finding and exchanging information. "Secondly, like the learning experience through research because I and my team had a very good cooperation. We talk a lot about how to produce the videos; we collect information and keep changing the information. I like it very much" (BS10). Furthermore, AS22 affirmed this point as she really enjoyed conducting surveys and producing videos with her team, even though she felt a bit shy in the beginning. "Despite being really shy to speak in front of audience and camera, personally speaking ... I like the learning experiences through doing research/survey together with classmates and producing video presentations also with them" (AS22). In short, data shows that most participants had pleasant learning experiences using MPA as they were involved in collaborative work.

Not only that the participants claimed that they liked learning using MPA due to the collaborative efforts they were involved in, some participants claimed that they learned how to work in teams based on their involvement in MPA. When asked what she had learnt in the process of completing the MPA project, AS14 claimed that she learnt how to work cooperatively with her teammates. "I learn how to cooperate in group work" (AS14). BS2 mentioned that MPA taught her how to communicate with other people especially in getting information. "Second, I learn on how to communicate with other people to get information and cooperate with them" (BS2). In addition, this point was also confirmed by BS5 as he mentioned that MPA taught him "new ways to communicate with my group" (BS5).

In addition, some participants shared their experiences on how the collaborative efforts in MPA helped them in their learning. Realizing the importance of collaborative skills, BS21 stated that in completing the MPA project, it enhanced his teamwork skills, an essential skill as university students. "I can also improve working in teams as we are university students" (BS21). Meanwhile, BS18 described her experience working in her team. She loved the fact that the collaborative effort made her closer to her classmates. She said that in the 
process, they conducted discussions to go through all their ideas and this process enhanced their relationship as well. "Because it teaches me to learn more about speaking, it also make my time more beneficial by hanging out with my video group. We sat together to review all our ideas and it make our relationship bond closer" (BS18). Similarly, AS3 stated that the cooperation between her team members enabled her to know her friends closer, which she did not know prior the project. "Able to know friends that never know before and cooperate to doing the research/survey and producing video" (AS3). Furthermore, AS22 stated that the collaborative work in MPA has caused them to be closer and they created a support system among the group members in supporting each other in academic and life. In addition, she said that working together has improved the quality of their work. "Sometimes, there are things that we can get much more or better when we do it together; we backup friends when they have problems doing assignments and other matters" (AS22). Some students stressed on the benefits of collaborative work where they can have discussion platform to share and exchange ideas. "I like when I am given the opportunity to discuss about the video" (AS6). "I also felt happy working with my groupmates. We get to share and exchanges ideas with other groups as well” (BS17).

In summary, MPA encouraged participants to work in teams and in the process the participants learned on how to work collaboratively. Due to the positive collaborative experiences, the participants had a pleasant learning experience.

\subsection{Acquiring new skills - technological knowledge and critical thinking}

Firstly, Data shows that participants gained new knowledge in the process of completing the MPA tasks. A lot of the participants mentioned that through MPA they had the chance to do something new that they have not done before in other learning settings. In contrast to popular belief that students in the era of globalisation has been trained in using technologies in education, some participants indicated that MPA provided a whole new experience to them in terms of learning. AS19 stated that prior to MPA, she had been sending assignments in the form of printed booklet. "It is a new thing that I do in my life because before this I just submit hardcopy to my teacher" (AS19).BS5 affirmed this point when he mentioned that it was his first time producing a video presentation. "First of all it give me a new experience on how to producing video presentation which I never do it before" (BS5). BS3 stated that she liked to be involved in MPA project because it was a new experience for her. "I like learning about research survey using Google Form because before this I have never use it" BS3. Another participant, BS16 noted that MPA opened up a series of new things and experience for her. "Based on the video presentation, I gained a lot of knowledge and experiences, making the video, presenting and doing the research. All new" (BS16). BS12 explained in greater detail on how MPA provided a new learning experience to her. According to her, the learning experience was a relatively new experience for her and she would recommend the learning approach to be implemented in other learning settings. "Of course I like it. Because I can learn new things like how to create documentary and the process. And I like to create and would like to suggest all people to create video or anything related to media." BS12. It seemed that through MPA the participants would be able to be more creative in presenting ideas. In the case of this study, information was represented in the form of video documentaries, which is quite relevant to the $21^{\text {st }}$ century knowledge representation.

Next, data shows that through MPA, the participants were able to acquire new skills such as critical thinking skills. The participants were put in circumstances that invoked thinking among them. AS17 stated through MPA, he and his team were involved in a critical thinking process as they were posed with a complex circumstance. Once the project was presented to them, they started thinking about how to present their ideas to the public in a documentary form. 'We also know what is mean by 'documentary' as we heard it the first time we think hardly how we can make a video about our issues and we must think about the concept of it" (AS17). In addition, the MPA project required the participants to venture into new things, find and manage information that is beyond the participants' prior knowledge BS1 stated that in order for them to complete the task, they have to think beyond the common parameters. She said that "To finish this tasks, I need to think out of the box and think differently from I used to be" (BS1). AS3 stated that "I can know the things that I didn't know and how to handle it before. I learned to do that, I needed to do things different from the things I know" (AS3). Furthermore, some students also commented that they were involved in a recursive process of finding, exchanging and reviewing information in order to complete the MPA tasks. BS10 claimed that they had a lot of discussion on how to produce the videos and in the process they kept on reviewing the information they have collected earlier. "We talk a lot about how to produce the videos, we collect information and keep changing the information" (BS10). Similarly, BS19 stated that they collectively reviewed all their ideas in completing the MPA tasks. "We sat together to review all our ideas and it make our relationship bond closer" (BS19). BS17 shared similar point when he mentioned that "We get to share and exchanges ideas with other groups as well". It was quite clear from the data that in completing the MPA tasks, students were involved in a critical thinking process where they had to gather information, review them and later 
exchange information with fellow friends and later analyzed and synthesized the information to create the video documentary.

In short, it was evidenced that through MPA, the participants acquired new skills such as technological and critical thinking skills.

\section{CONCLUSION}

In conclusion, the findings of the study showed that MPA promotes the development of collaborative, technological and critical thinking skills among students. Firstly, the students not only learned on how to communicate effectively and conduct collaborative work, they also had an enjoyable experience in working in teams. This shows that MPA provided students the chance to practice working effectively in in a network of people to achieve a mutual goal, which was completing the MPA project. This enhanced collaborative skills are in line with the requirement of $21^{\text {st }}$ century workforce as argued by McComas (2014) and Saavedra and Opfer (2012).

Secondly, the students acquired new skills when learning using MPA. Some students claimed that they learnt new things such as representing ideas and information in a multimodal form such as presented in their video documentaries. In addition, it was also evidenced that the students were involved in a complex thinking process while managing the MPA tasks. The students recounted their critical thinking process that involved finding, reviewing, exchanging and representing information. This process reflects the complexities of the skills required in the $21^{\text {st }}$ century skills as mentioned by Silva , 2009.

It seems clear that, Multiliteracies Project Approach (MPA) is an effective pedagogical approach in cultivating $21^{\text {st }}$ century skills that prepares students for $21^{\text {st }}$ century employment. The change and transformation of the global economy, the social world and the advancement of information and communication technologies require a shift from the traditional classroom pedagogical approach. Learners are now expected to be proactive, possess the ability to analyze, evaluate, and communicate information effectively using available technological innovations. In addition, learners are expected to be able to work in a network, involving collaborative and leadership skills. Rotherham and Wiliamham (2010) argued that in the $21^{\text {st }}$ century, lessons should center on students, which allow them to collaborate and work in authentic situations and engage with the community; however, she stated that it was seldom the case in classrooms everywhere. MPA is designed to do just that; providing an authentic learning experience, with complex and multifaceted tasks to cultivate $21^{\text {st }}$ century skills among the students. Thus, it is recommended for teachers to implement MPA in their own learning setting to achieve the $21^{\text {st }}$ century learning skills.

The limitation of this study is that it is conducted in a specific setting with a small number of students. However, the findings of the study do provide a substantial basis in supporting the future use of MPA in other learning contexts. Future research might be conducted on how MPA can be implemented in other multiple education contexts.

\section{ACKNOWLEDGEMENT}

This work was supported by the Malaysian Ministry of Education under FRGS Grant Nos: USIM/FRGS/FBU/32/51313.

\section{REFERENCE LIST}

Anstey, M., \& Bull, G. (2006). Teaching and learning multiliteracies: Changing times, changing literacies. Newark, DE: International Reading Association.

Borsheim, C., Merrit, K., \& Reed, D. (2008). Beyond technology for technology's sake: Advancing Multiliteracies in the twenty-first century. The Clearing House, 82(2), 87-90. doi: 10.3200/TCHS.82.2.87-90

Fariza Puteh-Behak \& Selamat, S. (2017). Exploring the use of multiliteracies approach to enhance employability skills among Malaysian university graduates. Advanced Science Letters. Vol 24, 5.

Fariza Puteh-Behak, Darmi, R., \& Mohamad, Y. (2015). Implementation of a Western-based Multiliteracies Pedagogy in Malaysia: A Socio-cultural Perspective. GEMA Online ${ }^{\circledR}$ Journal of Language Studies, 15(1).

Charles, A. S. (2008).From bitmaps to vector graphics: Today's multiliteracies. Journal of Maine Education, 


\subsection{7-21.}

Cope, B., \& Kalantzis, M. (2009a). Multiliteracies: New literacies, new learning. Pedagogies: An International Journal, 4, 164-195.

Cope, B., \& Kalantzis, M. New media, new learning. (2009b).In D. R. Cole \& D. L. Pullen (Eds.), Multiliteracies in motion: current theory and practice. London: Routledge.87-103.

Creghan,C \& Adair-Creghan, K. (2015). The positive impact of project-based learning on attendance of an economically disadvantaged student population: A multilayer study. Interdisciplinary Journal of Problem-Based Learning. 9 (2).

Chalermchai Chaichompoo. (2013). Implementing project-based instruction for students with low English proficiency: A classroom scenario. Linguaculture, 2.

Gee, J. P. (2000). New people in new worlds: Networks, the new capitalism and schools. In B. Cope \& M. Kalantzis (Eds.), Multiliteracies: Literacy learning and the design of social futures (pp. 43-68). London: Routledge.

Gee, J. P. (2002). New times and new literacies. In M. Kalantzis, G. Varnava-Skoura \& B. Cope (Eds.), New worlds, new literacies, new learning, new people: Learning for the future (pp. 59 - 83). Australia: Common Ground Publishing.

Grabil, J. T., \& Hicks, T. (2005). Multiliteracies meet methods: The case for digital writing in English education. English Education, 301-311.

Hepple, E., Sockhill, M., Tan, A. \& Alford, J.H. (2014). Multiliteracies pedagogy: Creating Claymations with adoslescent, post-beginner English language learners.

lyer, R., \& Luke, C. (2010). Multimodal, multiliteracies: Texts and literacies for the 21st century. In D. L. Pullen \& D. R. Cole (Eds.), Multiliteracies and technology enhanced education: Social practice and global classroom (pp. 18-34). New York: Information Science Reference.

Kist, W. (2003). Student achievement in new literacies for the 21st century. Middle School Journal, 35(1), 613.

Simon, R. (2011). On the human challenges of multiliteracies pedagogy. Contemporary Issues in Early Childhood. 12 (4). 362-366.

Markham, T. Project Based Learning. Teacher Librarian, 39(2). (2011). 38-42.

McComas, W.F. (2014). The Language of science education. SensePublishers. USA

Ooi, M.S. (2016, March 13). Making jobless grads employable. The Star Online. Retrieved from http://www.thestar.com.my

P21 Partnership for $21^{\text {st }}$ Century Learning (2016). Framework for $21^{\text {st }}$ Century Learning. http://www.p21.org/our-work/p21-framework

Silva,E. (2009). Measuring skills for the $21^{\text {st }}$ century learning. Phi Delta Kappan. 90(9). 630.

The New London Group. (2000). A pedagogy of multiliteracies. In B. Cope \& M. Kalantzis (Eds.), Multiliteracies: Literacy learning and the design of social futures. London. 9-37. LondoRoutledge.

Rotherham A.J. and Williamham, D.T (2010). $21^{\text {st }}$ century skills: Not new, but a worthy challenge. American Educator, Spring.p17-20

Saavedra, A.R. and Opfer, V.D. (2012). Learning $21^{\text {st }}$ century skills requires $21^{\text {st }}$ century teaching. Phi Delta Kappan. 94(2). P 8-13 